\title{
Regional and State Association News
}

\section{Northeastern Political Science Association}

The 25th Anniversary meeting of the Northeastern Political Science Association (NPSA) was held November 11-13, 1993, in Newark, New Jersey, with over 500 political scientists in attendance. This was the highest turnout in the association's history. The program was organized by the first vice president and program chair, Donald G. Tannenbaum of Gettysburg College, with the assistance of the officers and council members of both the NPSA and the Northeast International Studies Association. The schedule included 81 panels from among the many subfields of the discipline, as well as a number of cross-disciplinary sessions. An interesting contrast may be noted by comparing the program of the first NPSA conference, which was included in the packet of materials distributed at the latest meeting: in 1969 about 50 individuals participated in a total of eight panels.

One tradition has carried over from the first meeting to the twenty-fifth. In 1969, APSA President Karl Deutsch spoke to the members (the subject of his address was not recorded on the program, although it might well have been a warm-up for his APSA presidential address the following year), and in 1993 APSA President Charles O. Jones addressed the meeting on
"The President in a Separationist System." In 1993, another large audience heard Theodore Lowi, a past APSA president, speak at a special plenary session on "An Evaluation of the Clinton Administration After One Year."

\section{New Officers Elected}

At the annual business meeting the following were elected to serve on the Executive Council:

President: Donald G. Tannenbaum, Gettysburg College

First Vice President and Program Chair: Russell Harrison, Rutgers University, Camden

Second Vice President: Garrison Nelson, University of Vermont

Third Vice President: Nancy E. McGlen, Niagara University

Treasurer: Donald Buzinkai, King's College

Council Members: Thomas Baldino, Wilkes University; Jo Renee Formicola, Seton Hall University; Abdul Sedehi, Seton Hall University; Marcia Weigle, Bowdoin College; Norma Thompson, Yale University; Katherine L. Forhan, Siena College; Charlotte Patton, CUNY; Eugene Brown, Lebanon Valley College; ex-officio: ISA-NE representative, Robert Denmark, University of Delaware.

\section{Council Appoints First Executive Director and Welcomes New Editor of Polity}

Upon the retirement of its longtime secretary, David Rebovich of Rider College, the NPSA Council decided to include some of his functions in a newly created position, Executive Director of the Northeastern Political Science Association. The Executive Director's duties include assisting in the preparation of the annual program and communication with the NPSA membership. The Council selected as its first Executive Director Joseph Melusky, St. Francis College, a person who has given a number of years of service to both the NPSA and the Pennsylvania Political Science Association.

The Council and membership also had the opportunity to welcome M. J. Peterson, University of Massachusetts, Amherst, the new Editor of Polity, the official journal of the NPSA. Peterson assumes the post following the term of outgoing editor, Jerome M. Mileur, University of Massachusetts, Amherst.

Persons wishing to participate in the 1994 meeting of the NPSA, which will be held in Providence, Rhode Island, from November 10-12 should consult "Upcoming Conferences" in the March 1994 issue of $P S$. 